\title{
The Phenomena of "An Empty Box" and the Resistence of Pati People to the Oligarchy Domination in the Local Election Pati
}

\author{
Nur Hidayat Sardini ${ }^{1}$, Fitriyah $^{1}$ \\ ${ }^{1}$ Government Departement,Faculty Social and Political Science, Universitas Diponegoro,Semarang - Indonesia
}

\begin{abstract}
This research tries to highlight the phenomena of "an empty box" and society resistance to oligharchy formation in the regional election of Pati in 2017. Its aims are to find out the underlying factors, and other factors trigerring the existence of "an empty box" and society resistence. This research is qualitative with a case study method. The data was gained by interviewing informants deeply, and collecting secondary data. The results of research show that there are various models of general election with a single candidate, and various local society resistence to political oligarchy practices and formation also appear. Further, the weaknesses of political party recruitment as the sources of leadership and the greed of political elites are also revealed. Knowing the findings, a good arrangement to improve the function of political parties should be done. Then, for the future research the roles of oligarchy in regions as one of ways to control local political actors can be studied.
\end{abstract}

Keywords: Empty Box; Social Resistance; Oligarchy.

\section{Introduction}

General Election is a mean of people sovereignity to elect two or more candidates in which in the future one of them will be chosen as a leader of a particular country or region. The definition of general election is proposed on the assumption that voters elect consciously two or more candidates both at executive and legislative general election based on the process of deliberation democracy [1]. To determine the leader is usually based on the candidates who get the most votes. The point of the election known so far is that an election requires voters to choose one of two candidates or a number of candidates presented in the ballot.

The Pati Local Election in 2017, is inversely proportional to the preconditions of the election. In the elections of Pati in 2017, voters were only given an option in the ballot. They could only vote a pair of candidates, namely Haryanto as a candidate of Regent and Saiful Arifin as Regent vice candidate, while voters were also given an opportunity to choose "blank column" or "empty box." The Pati election model is actually unknown in the world. In Indonesia, it may occur as it becomes the Court Decision Number 100 / PUU-XII / 2015.

The candidates, Haryanto and Saiful Arifin were determined by Pati Election Commission (KPU) on
October 25, 2016, as a sole pair candidates, proposed by a large coalition of political parties. The coalition covers Partai Kebangkitan Bangsa (PKB, 6 seats, $12 \%$ ), Partai Keadilan Sejahtera (PKS, 5 seats, $10 \%$ ), Partai Demokrasi Indonesia Perjuangan (PDIP, 8 seats, $16 \%$ ), Partai Golkar, (6 seats, $12 \%$ ), Partai Gerakan Rakyat Indonesia Raya (Gerindra Party, 8 seats, $16 \%$ ) Partai Demokrat (6 seats, 12\%), Partai Persatuan Pembangunan (PPP, 3 seats, 6\%), and Partai Hati Nurani Rakyat (Partai Hanura, 4 seats, 8\%) [2]. This based on the number of DPR members of Pati Regency elected at Legislative Election 2014 which is 50 (fifty) seats [3].

The phenomena of the candidates gave various colors to the dynamics of voting day in Pati, 2017. It occured before, during, and after the election. In fact, political dynamics is intended to put the conflict of quality between political actors support the candidates, as well as an alternative power from Pati people. The first group plays the character of political oligarchy, while the second group plays the function of political balancing. The issue raised by the first party is the success campaign of petahana, while the second party criticizes the first-party performance which is considered greedy because it does not give any opportunity to other power in the General Election, as 
well as the support of petahana given to the investors solely during having the position of regent

\section{Methodology}

This is a qualitative research with primary and secondary data. This research have research questions written as follow: (1) What are the roles of "an empty box" and Pati people resistance to oligarchy dominance in the election of Pati Regent and his vice in 2017; and (2) What are the factors cause the strengthening of political articulation of "an empty box" and Pati people's resistance to oligarchy dominance in the election of Pati Regent and Regent vice in 2017 ?

\section{Discussion}

Elections. The objective of conducting the General Election is to determine who will hold the governmental position. In addition, its purpose is to maintain public control over the government, including throw the rascals out ${ }^{4}$. Oligarchy. In Oligarchy's book, Winters argues that the oligarchy is "the power of few people rule over many" through the mastery of games; and rules of play through the control of the material resources [5]. This opinion reflects the political economic of Indonesia, which places the oligarchy in the domination of power at the local level after Soeharto's power fell down. The very rich actors have dominated Indonesian democracy, and patronage becomes their glue. New Social Movements. The theory based on New Social Movement seeks to see the relationship between social movements, and structural and cultural changes on a larger scale. It also stresses on ideology, tactics and organisation, flexible movement structures, cross-social participants, and the free issue area [6].

The implementation of election in Pati, 2017 was more dynamic than in other regions. It can be seen from the phenomena appear such as the resistance of people in Pati to incumbent, the outbreak of money politics, and the local people's assessment on the performance of incembent regent as he has issued incumbent policies support the investors only.

The incumbent's favor to the investors is evidenced by the tendency of regent. Based on the "empty box" movement, the policies issued is more concerned with the construction of a cement factory than the society needs. A Kayen resident, Siti Qomariah, declared reluctantly to elect Haryanto-Saiful because she was disappointed to what they did. She viewed that the petahana candidates neglected some remote or outskirt areas in Pati when they were regent and regent vice [5]. However, when they were criticized because of neglecting their people, they said that " it is impossible for me to harm the people [7].

The recapitulation of vote gained by KPU of Pati shows that Haryanto and Saiful Arifin (Harifin) won the elections. Of the 1, 034, 256 voters, 324,219 people abstained, while those who voted the petahana candidates were 523,482 (75\%), and " an empty box" was elected by 172,004 voters $(24.27 \%)$ [8].Despite of winning the election, the candidates actually failed in reaching the target. This might related to the political activities and ones supported the "empty box." The target set by the candidates was $80 \%$ voters would support them [9]. Unluckily, in some polling stations the candidates were absolutely lost because of the empty box. Further, in other polling stations they got the lowest proportion of vote. The examples were the election held at Tulang Bawang Barat. The candidates earned $96.75 \%$ and empty box got 3. 25\%; at Landak the candidates got $96.62 \%$ and empty box had $3.38 \%$ vote.

The movement of "empty box" in the election in Pati began a long time ago before the voter registration. Then, the political landscape of their activity aims to control the power of oligarchy, shown by the figure of the regent and his the starter. The first issue carried by the activists of "empty box" is a movement against the oligarchy power in Pati. Secondly, the activists want to criticize the behavior of the regents, especially due to his ignorance about his people's needs, when a cement factory is built. Third, having the methods of populist movements in the form of social protests, rallies or convoys, having exercises with citizens, demonstrations, and other forms, they want to remind the citizens of Pati to use the rights of voting

The activists view that by having this way, they can stem the vote acquisition of petahana regent. "We exist as a part of democracy and become control and correction tools because in the election with a pair of candidates only, there is not any opponent directly controls the election." In this case, the target of activist movement is to win the vote because of the "empty box" and abstaining voters. Further, it may be possible to reach almost $50 \%$ of the vote, or at least $38.1 \%$, Therefore, they intensively campaign the ending of Pati people mandate to the regent.

There are two factors that rise to the Pati people's resistance movement. First is the underlying factors. They are the performance of the regent, and the ignorance of regent to his society. The society's indignation was expressed during a working visit of the regent to the village of Sinomwidodo Tambakromo on December 30, 2015. The regent was considered as the main figure forcing the establishment of a cement factory and mine in Tambakromo and Kayen, Pati. The regent has broken his promise to revoke the environmental permit no. 6601/4767.2014. Instead of keeping the promise by implementing the TUN Ruling, on the other day the regent and PT Sahabat Mulya Sakti appealed to PT TUN Surabaya.

Second is the precipitating factor. It is the regent's steps to collect support from political parties. Then, this strengthens the attitude of people to conduct the resistance movement. For the people of Pati, the regent is assumed to have favor to the cement factory so he collects as many as possible supports from the political party. This triggers an empty box movement. This movement began on January 26, 2017- a month before the Pati-Election. The empty box movement was expressed by conducting a casual event such as 
jogging and then, issuing a declaration of the movement.

The volunteers of the empty box movement were worried about cheating on the election day because of a single candidate at the election. Therefore, 2000 volunteers are ready to supervise the collection, counting and recapitulation of votes, not only at each polling station (TPS), but also at the next level, Kecamatan Selection Committee (PPK) and the Pati Regency KPU. An "empty box" volunteer, Karsono said that the movement appears as there is only a pair of candidates in the election.

The initiators of the empty boxes persuade the wider society to do some points written as follow. First is never going back home before voting, vote counting, recording the election results is completely done at each polling station. Second is be wary of money politics practices both before and during the voting. Here, the petahana candidates may have possibilities to do those practices. Third, they also work together with the election supervisors and the KPU to prevent, and process any possible fraud. Fourth is form volunteer teams at the district, sub-district, polling station. In each sub-district there is a District Coordinator (Korcam).

Politician need to concern on environmental issue. As an attempt to increase voters, politician have to put more attention to society welfare and healthy environment. Pati, as a city located in north coastal of Java Island needs reforestation program in order to make a comfortable environment and healthy society.

\section{Conclusion}

The empty box movement in the Pati Election, 2017 is a disappointed expression from society because of the petahana regent performance. In fact, the empty box is permitted because it is governed by the law of Regional Election and Constitutional Court's Decision. On the other hand, people who are members of nongovernmental organization take advantages on the performance of regent which is more favorable to the investors especially in the construction of cement factory as well as the regent's actions that does not give any chance to other candidates to have support from political party.

\section{References}

1. R. A. Dahl, Democracy and Its Critiques, New Haven, Yale University (1991).

2. KPU Pati, Laporan Pelaksanaan Tahapan Pencalonan Pemilu Bupati dan Wakil Bupati Pati Tahun 2017 (2017).

3. Keputusan KPU Pati No. 48/Kpts/KPU-Kab012.329311/2016 tentang Penetapan Pasangan Calon Bupati dan Wakil Bupati Pati (2017).

4. IDEA, Europe Commission, and UNDP Joint Task Force on Electoral Assistance, Elections, Violence, and Conflict Prevention on June 20-24, Sweden: IDEA International (2011).

5. J. A. Winter, Oligarki, Jakarta, Gramedia Pustaka Utama (2011).

6. T. Alain, Return of the Actor: Social Theory in Postindustrial Society, Minneapolis: University of Minneapolis Press (1998).

7. F. Fardianto, Pilkada Pati Kotak Kosong Politik Uang, Retrieved from http://www.rappler.com on 4 October 2017 (2017).

8. Z. Arifin, Jika Rugikan Rakyat, Bupati Pati Haryanto Tolak Pembangunan Pabrik Semen, Retrieved from http://jateng.tribunnews.com on 4 October 2017 (2014).

9. KPU Pati, Hasil Rekapitulasi Perolehan Suara Pilkada Pati, KPU Kabupaten Pati, Tahun 2017 (2017). 